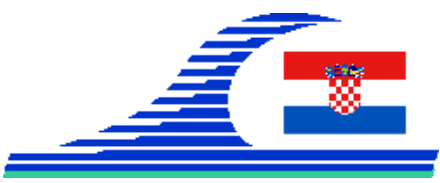

\title{
The rocky coasts of the Mediterranean Sea: field studies
}

\section{Stefano FURLANI ${ }^{1}$}

1. University of Trieste, Department of Mathematics and Geosciences, via Weiss 2, 34128 Trieste, Italy.

sfurlani@units.it

\begin{abstract}
:
Rock coasts cover more than half of the Mediterranean Sea coasts. FURLANI et al. (2014a) provided an extensive review of these kinds of coasts that are affected by vertical tectonic movements and changes in relative sea level and are generally characterized by mid- to low-storm wave energy. The Quaternary evolution of Mediterranean coasts have been widely studied, starting from different sea level markers, while increasing researches are addressing the processes related to the origin and evolution of rocky coasts. Despite most of the Mediterranean coast being rocky, studies about rocky shore processes are almost completely lacking, except for limited sectors. Data on sea cliff retreats have been collected to study the susceptibility of cliff failures or to prevent landslides, in particular along touristic shores. Moreover, data on erosion rates and processes on shore platforms are generally very scarce and usually regard limestone bedrocks.

Due to its geologically varied coastline and low-energy coastal regime, the Mediterranean basin represents an essential field laboratory for swim and snorkel surveys. The low-energy environment that characterizes the Mediterranean basin allowed researchers to carry out snorkel surveys along several sectors of rock coasts. Within the frame of the Geoswim project, more than $500 \mathrm{~km}$ were surveyed from 2012, in particular the Central Mediterranean Sea.

The aim of this work is to provide an overview of the results of geomorphological studies about rocky coasts in the Mediterranean area after FURLANI et al. (2014a), following in particular the results of the Geoswim project.
\end{abstract}

\section{Keywords:}

Coastal geomorphology, Rocky coasts, Sea level changes, Coastal scenery, Geoswim project, Mediterranean Sea 
Mediterranean rocky coasts:

Features, processes, evolution and problems

\section{Introduction}

The Mediterranean Sea is bordered by about $23.000 \mathrm{~km}$ of rocky coasts (FURLANI et al., 2014a). Despite the high percentage of rocky coasts in the Mediterranean Sea (more than 50\%), the literature is limited and it has received little attention in papers and textbooks. Moreover, the scientific literature on rocky coasts in the Mediterranean Sea, but also in the remaining world's rock coastlines, was almost completely neglected with respect to low-lying coasts (EMERY \& KUHN, 1982). Data regarding cliff retreat can be partly inferred from technical reports or geoengineering papers (BUDETTA et al., 2000). Field measurements of rock erosion rates started after the 1980s, along limited limestone coastal sectors (TORUNSKI, 1979; FURLANI et al., 2009). During the last decade process-based literature increased, but with only a few studies focused on the Mediterranean Sea rocky shores (GOMEZ-PUJOL et al., 2006; ANDRIANI \& WALSH, 2007; FURLANI et al., 2009; CHELLI et al., 2010), in particular some aspects, such as tsunamis and deposits of large boulders (MASTRONUZZI, 2010).

Recently, the Geoswim project, which aims at surveying by snorkelling rock coasts in the Mediterranean Sea, added significant amount of geological and geomorphological data (FURLANI et al., 2014a, b; 2017a, b).

Our aim is to provide an overview of the geomorphological issues and to review the rare results of the studies concerning the rates and processes of rocky coast evolution in the MBS.

\section{Swim and snorkel surveys in the Mediterranean basin: the Geoswim project}

The availability of very detailed remote data both in the subaerial and underwater environment, such as respectively LiDAR and Multibeam data, cannot satisfactorily contribute to describe the intertidal zone and its related forms, such as tidal notches. In particular, the high slope and the sea interface along vertical or sub-vertical plunging cliffs prevent the acquisition of these data; therefore swimming is a very useful method for visual observations and rough morphometric measures. Swim survey allows geomorphological, hydrogeological and ecological observations that are very localized in time, but wide in space, along all the perimeter of surveying. Rough observations of the geomorphological and ecological variability of the intertidal zone along wide sectors of rocky coasts can be carried out. The accuracy of observations increases with increasing calm sea and good weather conditions, so the method can be very useful in close sea basins, such as the Mediterranean, rather than in ocean basins, where tides are wider and waves are higher.

The snorkel surveys carried out in the frame of the Geoswim project adopted the protocol suggested by FURLANI et al., (2014b, 2017a, b). The surveys are carried out using snorkel observations at $\sim 1 \mathrm{~m}$ from the shoreline, following the favourable wind driven currents. The speed survey is roughly $1 \mathrm{~km} / \mathrm{h}$ but depends on the environmental conditions during the snorkel activities. 
Mediterranean rocky coasts:

Features, processes, evolution and problems

A specially designed raft, $1 \mathrm{~m}$ long, which can be pushed or dragged, is used to house all the surveying equipment during the snorkeling activities. The instrument on the raft and the activities during the survey are following described:

a) Underwater cameras: One or more cameras (GoPRO, etc) are located in a semisubmerged dome in order to collect time-lapse images of the tidal zone.

b) CTD and other sensors: CTD sensors are located at increasing depths up to $0.5 \mathrm{~m}$ b.m.s.l. in order to measure differences in electrical conductivity and temperature along the surveying perimeter.

c) Sounder: An echosounder allows to collect bathymetric data along the surveying perimeter. Trasects are collected at significant distances or at prominent sites.

d) Field observations: Visual observations are collected and georeferenced during the survey. All information is collected by the operator on the support vessel.

e) GPS: Data collected during the survey are georeferenced using one or more GPS. Some sensors include an internal GPS.

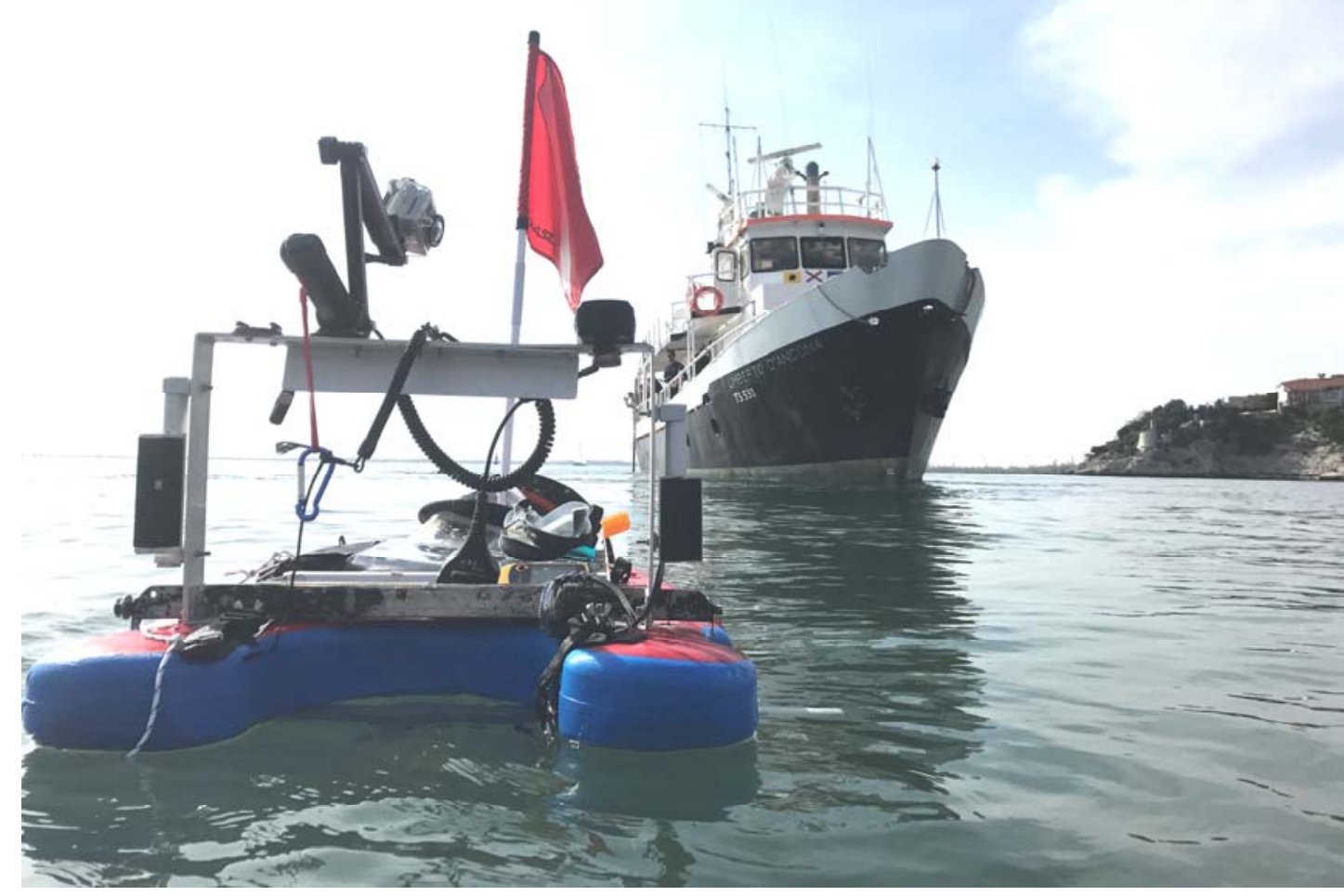

Figure 1. The 1.2 m-long raft, called "Barchino", used for the snorkel surveys. Here the raft during a surveying test along the coastal sector between Sistiana and Duino, Gulf of Trieste (Italy). 
Mediterranean rocky coasts:

Features, processes, evolution and problems

From 2012, more than 500 kilometers were surveyed using the Geoswim protocol, and other 300 kilometers to test new instruments and to survey some sectors of coast again. While the first campaign, along the western Istrian coasts and the Gulf of Trieste, was carried out in solitaire, the others were completed by teams of students and researchers working together. Table 1 summarizes the sectors and the total length of the Geoswim campaigns since 2012.

Table 1. The Geoswim project campaigns.

\begin{tabular}{llll}
\hline Year & Location (area of survey) & Total length of survey $(\mathbf{k m})$ & Type of survey \\
\hline 2012 & Istrian coasts (Croatia, Slovenia, Italy) & 260 & One-man survey \\
2013 & Gozo and Comino (Malta) & 70 & Team \\
2014 & Egadi Islands, Sicily (Italy) & 70 & Team \\
& Ustica (Italy) & 14 & Team \\
2015 & N Sardinia (Italy) & 80 & Team \\
& SW Istria (Croatia) & 7 & Team \\
2016 & Monte Conero, W Adriatic (Italy) & 2 & Team \\
2017 & Paros Island (Greece) & 24 & Team \\
\hline
\end{tabular}

\section{Conclusions}

This work demonstrates that rock coasts are significant landforms along much of the Mediterranean coasts, but few studies have explored their erosion rates, rock decay processes and related forms. Quantitative data on cliff retreat and the erosion of shore platforms are rare and restricted to limited sectors.

Although the Quaternary evolution of the Mediterranean coast has been extensively studied, process-related studies on rocky shore processes are almost completely lacking. Geomorphological evidence provided in this chapter suggests that this area is potentially very promising for studies on rocky shores. The presence of large sectors of carbonate coasts provides great potential to study those processes, typical of coastal karst under variable, but not extremely different, climate conditions.

The low-energy setting of many sectors of the Mediterranean basin allowed snorkelsurveying along many rock coast sectors within the Geoswim project from 2012.

\section{Acknowledgements}

I'm very grateful to all the researchers, students and friends who support from many years the Geoswim project. Special thanks go to Rados Furlani for technical assistance and to Navionics for echosounder instruments. 
Mediterranean rocky coasts:

Features, processes, evolution and problems

\section{References}

ANDRIANI G. F., WALSH N. (2007). Rocky coast geomorphology and erosional processes: a case study along the Murgia coastline South of Bari, Apulia - SE Italy. Geomorphology, Vol. 87, pp. 224-238. doi.org/10.1016/j.geomorph.2006.03.033

ANTONIOLI F., LO PRESTI V., ANZIDEI M., DEIANA G., DE SABATA E., FERRANTI L., FURLANI S., MASTRONUZZI G., ORRU' P., PAGLIARULO R., ROVERE A., SANNINO G., SANSO’ P., SCICCHITANO G., SPAMPINATO C.R., VACCHI M., VECCHIO A. (2015). Tidal notches in the Mediterranean Sea: a comprehensive analysis. Quaternary Science Review, Vol. 119, pp. 1-19. doi.org/10.1016/j.quascirev.2015.03.016

BUDETTA P., GALIETTA G., SANTO A. (2000). A methodology for the study of the relation between coastal cliff erosion and the mechanical strenght of soil and rock masses. Engineering Geology, Vol. 56, pp. 243-256. doi.org/10.1016/S0013-7952(99)00089-7 CHELLI A., PAPPALARDO M., AROZARENA LLOPIS I., FEDERICI P. R. (2010). The relative influence of lithology and weathering in shaping shore platforms along the coastline of the Gulf of La Spezia (NW Italy) as revealed by rock strength. Geomorphology, Vol. 118, pp. 93-104. doi.org/10.1016/j.geomorph.2009.12.011

EMERY K.O., KUHN G. G. (1982). Sea cliffs: their processes, profiles, and classification. Geological Society of America Bulletin, Vol. 93, pp. 644-654. doi.org/10.1130/0016-7606(1982)93<644:SCTPPA>2.0.CO;2

FURLANI S., CUCCHI F., FORTI F., ROSSI A. (2009). Comparison between coastal and inland Karst limestone lowering rates in the northeastern Adriatic Region (Italy and Croatia). Geomorphology, Vol. 104, pp. 73-81. doi.org/10.1016/j.geomorph.2008.05.015 FURLANI S., PAPPALARDO M., GOMEZ-PUJOL L., CHELLI A. (2014a). The rock coast of the Mediterranean and Black Seas. in: Kennedy, D.M., Stephenson, W.J., Naylor, L.A. (Eds), Rock Coast Geomorphology: A Global Synthesis. Geological Society, London Memoirs, Vol. 40, pp. 89-123. doi.org/10.1144/M40.7

FURLANI S., NINFO A., ZAVAGNO E., PAGANINI P., ZINI L., BIOLCHI S., ANTONIOLI F., COREN F., CUCCHI F. (2014b). Submerged notches in Istria and the Gulf of Trieste: results from the Geoswim Project. Quaternary International, Vol. 332, pp. 37-47. doi.org/10.1016/j.quaint.2014.01.018

FURLANI S., ANTONIOLI F., GAMBIN T., GAUCI R., NINFO A., ZAVAGNO E., MICALLEF A., CUCCHI F. (2017a). Marine notches on the Maltese Islands (Central Mediterranean Sea). Quaternary International, Vol. 439, pp. 158-168. doi.org/10.1016/j.quaint.2016.03.004

FURLANI S., ANTONIOLI F., CAVALLARO D., CHIRCO P., CALDARERI F., FORESTA MARTIN F., GASPARO MORTICELLI M., MONACO C., SULLI A., QUARTA G., BIOLCHI S., SANNINO G., DE VITA S., CALCAGNILE L., AGATE M. (2017b). Coastal landforms and Late Quaternary relative sea level changes at 
Mediterranean rocky coasts:

Features, processes, evolution and problems

Ustica (Sicily, southern Italy). Geomorphology, Vol. 299, pp. 94-106. doi.org/10.1016/j.geomorph.2017.10.004

GOMEZ-PUJOL L., CRUSLOCK E.M., FORNOS J.J., SWANTESSON J.O.H. (2006). Unravelling factors that control shore platforms and cliffs in microtidal coasts: the case of Mallorca, Catalonian and Swedish coasts. Zeitschrift fur Geomorph., Supplementbande, Vol. 144, pp. 117-135.

MASTRONUZZI G. (2010). Tsunami in Mediterranean Sea. The Egyptian Journal of Environmental Change, Vol. 2, pp. 1-12.

TORUNSKI H. (1979). Biological erosion and its significance for the morphogenesis of limestone coasts and for nearshore sedimentation (northern Adriatic). Senckenbergiana maritime, Vol. 11, pp. 193-265. 